\title{
Gav det mening, skat?
}

Af Camilla Heding Andersen, Lotte Maglehøj Hansen, Morten Willas Lund og Søren Obed Madsen*

"How do you learn from such tragedies? - Do you learn? Is the focus on learning or 'the politics of blame'?"

Scott A. Snook

\section{Resume}

Denne artikel tilbyder en alternativ forståelse af udbyttesagen end den forståelse, de hidtidige undersøgelser og rapporter har givet. Vi analyserer SKAT ud fra Weicks teori om meningsskabelse, og hvorfor organisationer kollapser. Vi ønsker at forklare, hvordan det kunne ske på trods af, at der har været etableret mange kontrolinstanser og ledelsesmekanismer. Artiklen ønsker ikke at finde den eller de skyldige i SKAT, fordi hvad hvis svindlen med udbytteskat simpelthen er et resultat af en kæde af hændelser i en proces af meningsskabelse? Vores analyse peger på, at de eksisterende analyser har overset konsekvenserne af manglende meningsskabelse, samt magtforholdet til Finansministeriet og konsulenthusene, der gemte sig i kulissen, New Public Management-paradigmet og politiske visioner om en effektiv offentlig sektor. Artiklen afsluttes med en refleksion om, at det meningstab, vi har set i SKAT, ser vi også begyndende tegn på i andre dele af den offentlige sektor.

* Camilla Heding Andersen er kommunikationsansvarlig på Suhrs Højskole; Lotte Maglehøj Hansen er Sektionschef i Forsvaret; Morten Willas Lund er HR Chef, Amager og Hvidovre Hospital, Region Hovedstaden; og Søren Obed Madsen er adjunkt ved Institut for Ledelse, Politik og Filosofi, CBS 


\section{A. Indledning}

\section{Baggrund. Når en offentlig organisation kollapser}

At offentlige organisationer kollapser foran øjnene på os, er ikke noget, vi oplever ofte. Med synet af SKAT, der i løbet af de seneste år er blevet ramt af skandale efter skandale, for til sidst i 2018 at blive delt op i syv nye styrelser, er der dog tale om et hidtil uset kollaps af en offentlig organisation i en dansk kontekst.

For at blive klogere på, hvorfor organisationer overhovedet kan kollapse, skrev vi masteropgave om svindlen med udbytteskat for 12,3 mia. kr. (Andersen, Hansen, og Lund, 2017). Vi ønskede at få en forståelse for, hvordan og hvorfor dette kunne finde sted. Vi har valgt netop denne case, der er Danmarkshistoriens største svindelsag, fordi den forløb over en årrække, uden at der blev grebet ind, dette endda på trods af talrige advarsler og påtegninger internt i SKAT. Der er på nuværende tidspunkt blevet gennemført fem større undersøgelser om sagen, uden at der er placeret et endeligt ansvar. Sagen er derfor oplagt som casestudie, fordi den kan give detaljeret viden om et organisationskollaps, og endvidere er afgrænset i både tid og rum. Denne artikel er en kondenseret udgave af vores opgave.

\section{Formål og problemstilling}

“Hvorfor kollapser organisationer?” og "Hvordan kan organisationer gøres mere resiliente?” (Weick, 1993, s. 628). Disse to spørgsmål stiller Weick i sin analyse af historien om 'The Mann Gulch Disaster'. En historie, der i Weicks optik er eksemplet på det ultimative organisationskollaps. Mann Gulch Disaster er beretningen om en gruppe brandmænd, der fejlfortolker en brand, hvilket fører til et meningstab blandt brandmændene og ender med at få fatale konsekvenser, da 13 ud af 16 brandmænd dør som følge deraf.

Med udgangspunkt i, hvad der skete i SKAT, og hvad der muliggjorde, at svindelen med udbytteskat for 12,3 mia kunne finde sted, stiller vi i denne artikel de samme to spørgsmål, som Weick stiller ved sin analyse af Man Gulch. Ved at undersøge meningsskabelsesprocessen i SKAT ser vi, at meningsskabelsen har den følgevirkning, at medarbejderne i SKAT handlede uden egentlig at handle, og at svindlen fandt sted, selvom næsten alle de implicerede forsøgte at gøre deres arbejde så godt, som de kunne. Med andre ord kan kan der ikke udpeges en ansvarlig, og ingen enkeltpersoner kan drages til ansvar for sammenbruddet i SKAT. Kollapset i SKAT blev i 
stedet skabt på baggrund af et kompleks samspil af flere faktorer. Vores analyse peger på, at de eksisterende rapporter har overset konsekvenserne af dette samspil og ikke mindst fire konkrete underliggende faktorer, der havde afgørende betydning for sammenbruddet. De fire faktorer er 1. magtforholdet til Finansministeriet, 2. konsulenthusene, der gemte sig i kulissen, 3. New Public Management-paradigmet og 4. politiske visioner om en mere effektiv offentlig sektor.

Denne artikel tilbyder således en alternativ forståelse af udbyttesagen, end den forståelse de hidtidige undersøgelser og rapporter har givet. Ved at kigge væk fra ansvar og i stedet søge at få et indblik i meningsskabelsen i SKAT, ved hjælp af Weicks syn på organisationer som løst koblede systemer, håber vi at kunne bidrage til en bedre forståelse af, hvorfor kollapset i SKAT kunne finde sted, og hvordan vi i fremtiden kan forhindre, at det sker i andre organisationer.

\section{Oversigt over artiklen}

Artiklen starter med en kort gennemgang af teorien om meningsskabelse. Derefter beskriver vi vores metode. Efter denne beskrivelse analyserer vi de fem rapporter om SKAT, før vi går i gang med analysen af meningsskabelsesprocessen i SKAT på medarbejder-, ledelses- og organisationsniveau. Ved at gennemgå de meningsskabende elementer på disse tre niveauer kan vi efterfølgende tegne et kausalkort over de begivenheder, der blev afgørende for, at svindlen fandt sted. Kortet viser, at ansvaret og problemerne ikke ligger hos enkeltpersoner eller i enkelte handlinger, men at kollapset i SKAT fandt sted på baggrund af et komplekst mønster af flere meningsskabende elementer i kombination. Ved brug af Weicks teori om meningsskabelse (Weick, 2001, s. 460) viser vi endvidere, hvordan manglen på improvisation, visdom, respektfuld interaktion og kommunikation blev afgørende for, at organisationen ikke havde den nødvendige resiliens til at kunne modstå kollaps.

\section{B. Teori}

\section{Meningsskabelse og forandringer i organisationer}

Med udgangspunkt i sin interesse for ledelse i organisationer fremhæver Weick katastrofer som værende illustrative for den virkelighed, moderne ledere i stigende grad opererer i. En virkelighed, hvor organisationer udgøres af "small, temporary outfits where the stakes are high, turnover is chronic, foul-ups can be spread, and the unexpected is common" (Weick, 1996, s.143). På den måde udsættes moderne organisationer ofte - ligesom i Mann Gulch 
katastrofen - for pludselige og farlige meningstab (ibid.).

Weick anvendte analysen af Mann Gulch-katastrofen til at udvikle sin teori om meningsskabelse og organisationers kollaps. Han argumenterer for, at skylden for et organisationskollaps normalt ville blive tillagt en mislykket strategi (implementering). Men som han viser i eksemplet med Mann Gulch-katastrofen, så vil mange organisationer ofte opleve denne type af pludselige rolleforandringer, som mindre misforståelser, der tilsammen ender med at få store konsekvenser. Selv organisationer, der tilsyneladende er ret standhaftige og solide, kan ifølge Weick kollapse under sådanne omstændigheder (Weick, 1993, s. 632-633. Weick, 1996, s. 144).

\section{Meningsskabelse}

Weick (2001, s. 460) beskriver meningsskabelse som: "Sensemaking is about sizing up a situation, about trying to discover what you have while you simultaneously act and have some effect on what you discover. Sensemaking, in other words is seldom an occasion for passive diagnosis" Meningsskabelse er altså kun sjældent en passiv diagnose, men et forsøg på at både forstå og agere i en situation, man samtidig selv er med til at påvirke. Videre er det ifølge Weick væsentligt at adskille meningsskabelse (sensemaking) fra beslutningstagen (decision making), fordi "sensemaking sets the frame within which decisions are made" (Weick, 2001, s. 460). Dermed sætter meningsskabelse rammen for beslutningstagning.

\section{Rolleforandringer og meningstab}

Brandmændene i Mann Gulch-katastrofen stod ikke overfor klare spørgsmål om, hvor de skulle gå hen, og hvordan strategien skulle være. De blev ramt af en mere basal og skræmmende følelse af, at de ikke længere kunne udfylde deres rolle som brandmænd, fordi de befandt sig i en situation, de ikke tidligere havde været i og ikke kunne få greb om, hvad der skete (Weick, 1996, s. 144-145). Efterhånden som begivenhederne tog fart, mistede den lille organisation af 16 brandfolk sin struktur, brandmændene blev nervøse og havde svært ved at finde mening i situationen. Tilsammen betød det, at de var ude af stand til at finde mening i den ene ting, der kunne have reddet deres liv (ibid.).

Weick operationaliserede idéen om meningsskabelse ved at opstille syv forskellige elementer, som forklarer, hvordan mening skabes (Weick, 1995). De syv elementer er individuelt uafhængige og 
skal ikke opfattes som en analytisk trappe, hvor meningsskabelsen kan rangordnes (Hammer og Høpner, 2015).

De syv meningsskabende elementer er:

1. Meningsskabelse som social proces - meningsskabelse sker i samvær med andre, enten ved fysisk eller oplevet samvær. Det er relationen mellem mennesker, der skaber mening

2. Meningsskabelse tager udgangspunkt i identitet - Hvis individets opfattelse af sig selv ændres, ændres meningsskabelsen

3. Meningsskabelse sker retrospektivt - Mening skabes bagudrettet og ikke i samme moment, som forstyrrelsen indtræffer.

4. Meningsskabelse er fokuseret på og udgår fra ledetråde - mening skabes ud fra elementer af en helhed. Individer fokuserer på enkelte elementer, og skaber derefter mening med helheden.

5. Meningsskabelse er en kontinuerlig proces og har ikke en begyndelse eller en slutning, men ligger i forlængelse af tidligere forstyrrelser.

6. Meningsskabelse er drevet af plausibilitet - ikke af akkuratesse. Mening skabes på baggrund af plausible observationer eller forklaringer, der ikke nødvendigvis er sande, logiske eller 'rigtige'

7. Handling ('enactment') er helt centralt i meningsskabelse, og skal vise, at verden ikke er noget på forhånd givet, men noget mennesket til dels selv konstruerer (Hammer og Høpner, 2015).

\section{Resiliens}

Ved at opbygge organisatorisk resiliens kan man ifølge Weick påvirke en organisations evne til at gennemleve, eller sågar overleve, kriser. Det vil sige, at en organisations resiliens kan medvirke til at modstå et kollaps. For i organisationer, hvor meningsskabelse sker i miljøer, der udsættes for pludselige skift fra det forventede til det uventede eller sågar til det ubegribelige, vil den resiliente organisation have større overlevelsesevne (Weick, 1996, s. 145). Ifølge Weick har resiliens fire karakteristika: Improvisation, visdom, respektfuld interageren og kommunikation.

Det er centralt at være opmærksom på direkte forbundne elementer i strukturer. Strukturer, 
forstået som konstitutive relationer mellem mening og rammer, er ifølge Weick sårbare. Måske mere end vi troede. For hvis en af dem nedbrydes, er der risiko for, at nedbrydningen spredes og forstærkes. "Meaning affects frameworks, which affects meaning" (Weick, 1993, s. 645). Dette anfører Weick for at tydeliggøre, at de ovenfor nævnte karakteristika ved resiliens skaber strukturer. "The Mann Gulch disaster is a case in which people were unable to negotiate strangeness. Frameworks and meanings destroyed rather than constructed one another" (Ibid.). Hovedpointen er dermed, at processer, der gensidigt konstituerer hinanden, også har evnen til gensidigt at destruere hinanden (Ibid.).

\section{SKAT som tæt eller løst koblet system}

Sagen er, ifølge Weick, at vi som oftest anskuer organisationer i et perspektiv, der ikke rækker i forhold til situationer, hvor rollestrukturer nedbrydes, og der forekommer meningstab. For når mange rolleforandringer sker, og de små fejl opstår, er det ikke beslutningen, der styrer slagets gang. Det skyldes, at "the world of decision making is about strategic rationality, and is built from clear questions and answers that attempt to remove ignorance". Mens "The world of sensemaking is about contextual rationality. It is built out of vague questions, muddy answers and negotiated agreements that attempt to reduce confusion" (Weick, 1996, s. 144). Derfor inddrager vi perspektiverne på, om en organisation er tæt- eller løst koblet.

I et tætkoblet system som i det klassiske, weberianske perspektiv på organisationer fokuseres der på motivation, driftsledelse og effektivitet samt et fast og klart hierarki med en tydelig arbejds- og ansvarsdeling. Ledelse forstås som scientific management, der sker via lederens funktion og ikke person. Lederen skal via sin ledelse udover at bidrage til organisationens egen stabilitet, også bidrage til samfundets. Weber anså således organisationen for at udgøre et legitimt og rationelt bureaukrati, hvori den ansatte arbejder i en ikke personlig relation og med embedet som kald. Centralt for det klassiske perspektiv er desuden regelstyring, idet tanken er, at organisering reducerer usikkerhed, blandt andet ved gennem formelle strukturer at gøre handlinger forudsigelige. Dette sker gennem standardisering og regulering, blandt andet udtrykt i organigrammer samt funktionsbeskrivelser (Vikkelsø og Kjær, 2014, Berg-Sørensen, 2013).

Når man forstår en organisation i det klassiske perspektiv, vil det være naturligt at tilgå analyser af utilsigtede hændelser ved at kortlægge de organisatoriske opgaver, hvorved det også er muligt at forstå roller og placere ansvar. Fokus i det klassiske perspektiv vil derfor være på at undersøge, 
hvem der har haft ansvaret for at udføre en opgave, hvordan der er blevet kontrolleret, og hvem der har haft det ledelsesmæssige ansvar. En undersøgelse, udarbejdet ud fra en klassisk organisationsopfattelse, vil således ofte have det mål at kunne placere ansvaret for, at det utilsigtede kunne ske. Dette perspektiv ses i den nye analyse af SKAT fra Jørgen Grønnegård Christensen og Peter Bjerre Morten (2018).

I Weicks perspektiv på organisationer er fokus ikke på ansvar og enkeltpersoner, men i stedet på sociale processer, og det er gennem disse sociale processer, organisationer udvikler sig: "I organisationer opstår adskillige meningsskabende sekvenser forskellige steder, som er lost koblede, og hvor det er det samlede monster af til- og fravalg, som har indflydelse på, om organisationen overlever eller forsvinder" (Hammer og Høpner, 2015). I nedenstående analyse har vi således valgt at anskueliggøre det mønster af meningsskabende sekvenser, der havde indflydelse på de til- og fravalg, der fandt sted i SKAT i tiden omkring udbyttesvindlen.

Organisationer skal ses som processer, der er konstant skabende i en proces mellem de skabende individer i organisationen og omgivelserne (Vikkelsø og Kjær, 2014). SKAT består således af individer, der i kontinuerlige processer skaber organisationen, hvorved det at organisere sig er en form for meningsskabelse. Endvidere er organisering ifølge Weick "et falles vedtaget grundprincip til at reducere flertydighed gennem meningsfulde gensidigt betingede handlinger" (Hammer og Høpner, 2015). Det betyder, at det er nødvendigt at anskue medarbejdere og ledere i SKAT som nogle, der i en dualistisk proces skaber nærhed til hinanden gennem gensidigt betingede handlinger, der samtidigt konstant er på vej vak fra hinanden (Hammer og Høpner, 2015).

SKAT er dermed i konstant bevægelse i et løst koblet system, hvor meningsskabelsesprocesserne betyder, at der ikke er én person, der bestemmer, men “at magten er gjort mulig gennem et monster af alliancer, som eksisterer inden for gruppen”(Hammer og Høpner, 2015). Dette står i diametral modsætning til den klassiske organisationstankegang om, at det er gennem den magt, lederne udøver, organisationen styres. Når SKAT ses som et løst koblet system, kan lederen muliggøre sin magtudøvelse gennem et mønster af alliancer.

I det klassiske perspektiv er specialisering og klar arbejdsfordeling en forudsætning for et velfungerende bureaukrati., og som vi vi vil vise, er SKAT opbygget derefter. Men i Weicks optik er det væsentligt for organisationer at fokusere mere på generelle kompetencer end på specifikke, da specialiserede systemer er mere sårbare end generaliserede og selvorganiserende. Ser man på 
SKAT i det perspektiv, er organisationen et sårbart system af specialiserede individer. Dette er helt centralt for forståelsen af kollapset i SKAT. For ved at anse SKAT som et løst koblet system, bevæger vi os væk fra grundantagelsen om, at det alene er udøvelsen af ledernes magt og korrekte forretningsgange, der er afgørende for, hvad der er sket i SKAT.

\section{Metode}

Da vi valgte udbytteskatteskandalen som vores case, var vi klar over, at det var en case, som havde stor politisk, juridisk og mediemæssig opmærksomhed. Vi oplevede også, at både nuværende og tidligere ansatte enten ikke kunne eller ville lade sig interviewe på grund af den af regeringen igangsatte advokatundersøgelse. SKAT og Skatteministeriet afviste også at deltage af samme årsag. Derfor måtte vi tænke kreativt. Vi interviewede tre tidligere ansatte i SKAT og Skatteministeriet, herunder to højtstående chefer. Vi interviewede desuden fire personer, der via deres arbejde på nyhedsmedier, universitet og fagforening havde et indgående kendskab til sagen. Gennem disse interviewpersoner fik vi adgang til materiale og rapporter, som de gennem deres arbejde med sagen havde haft adgang til. Sidst men ikke mindst analyserede vi fire offentligt tilgængelige rapporter om udbyttesagen samt offentlige uddrag fra Kammeradvokatens hemmeligholdte rapport. Endvidere har vi gjort brug af SKAT's og Skatteministeriets hjemmeside til at finde pressemeddelelser, konsulentrapporter samt andre officielle dokumenter om sagen. Vi har derudover benyttet os af artikler og dokumentarprogrammer vedrørende skattesagen i fagblade og nyhedsmedierne. Endelig har vi søgt og fået aktindsigt i forhold vedrørende personale og organisering i SKAT og Skatteministeriet, der kunne hjælpe os med at belyse sagen.

Vi har i vores analysestrategi ladet os inspirere af bogen "Friendly Fire: The accidental shootdown of U.S. Black Hawks over Northern Iraq” (2002) af Scott A. Snook. Heri gengiver og analyserer Snook et umiddelbart uforklarligt organisationskollaps. Snook gennemgår i bogen hændelsen, der førte til, at to amerikanske F-15 jagerfly den 14. april 1994 skød to, ligeledes amerikanske, Black Hawk-helikoptere ned i det, der i fagsprog kaldes friendly fire. Alle 26 ombordværende blev dræbt. Med sin gengivelse af nedskydningen giver Snook svar på, hvad der skete op til, at nedskydningen fandt sted og selve omdrejningspunktet for hans analyse er, hvorfor ulykken kunne ske (Snook, 2002, s. 18). Snook ønsker med andre ord at skabe mening i ulykken (Ibid.). Snook benytter triangulering til at belyse friendly fire-nedskydningen ved hjælp af flere forskellige kilder, herunder vidneudsagn og tekniske redegørelser. Han sammenligner således 
forskellige datakilder, forskellige evaluatorer eller efterforskeres undersøgelseskonklusioner, og han giver forskellige perspektiver på de samme datakilder og forskellige metodemæssige tilgange (Snook, 2002, s. 17). Dette har han kunnet gøre, fordi der på forhånd eksisterede enorme mængder af empirisk materiale om nedskydningen (Weick, 2001, s. 148).

Med udgangspunkt i tre hovedårsager for nedskydningen foretager Snook således en analyse af disse på hhv. individuelt-, gruppe- og organisatorisk niveau. For at skabe et ophæng til sine analyser udarbejder Snook både en detaljeret tidslinje for begivenhederne, der førte til ulykken, samt et komplekst kausalkort ('casual map'), der viser årsags-virknings sammenhænge i tid og sted (time and proximity) helt tilbage fra Sovjetunionens fald. Han starter således sin analyse ved selve nedskydningen og arbejder sig efterfølgende tilbage i tid. Med kausalkortet viser Snook, hvordan de tre hovedårsager til nedskydningen var vævet ind i tidligere hændelser, fjerne begivenheder og menneskelige fejltagelser, der enten på individ-, gruppe- eller organisatorisk niveau var med til at påvirke de handlinger og den meningsskabelse, der foregik umiddelbart op til nedskydningen. Årsags- og virkningsforholdene er således vævet ind i hinanden på en måde, hvor årsager stikker af fra virkninger, for siden at mødes igen.

Vi har således ligesom Snook valgt at gøre brug af de eksisterende analyser og rapporter, som baggrund for vores analyse af udbyttesagen, en analyse vi inspireret af Snook også har valgt at lave på tre forskellige niveauer, hhv. medarbejder-, ledelses- og organisationsniveau. Vi har ligeledes udarbejdet en detaljeret tidslinje over begivenhederne i udbyttesagen, og det har på denne baggrund været muligt for os at lave et kausalkort af sammenhænge, der fører os helt tilbage til Ronald Reagan og den neoliberale idé, samt Lykketofts og Eldrups reformering af Finansministeriet i 1992.

\section{Analyse}

Selve analysen består af to overordnede dele. Den første tager udgangspunkt i SKAT som en tætkoblet organisation og analyserer de tilgængelige rapporter og undersøgelser.

I analysens anden del dykker vi ned i Weicks teori om løst koblede systemer som sociale processer, for at få belyst, hvorledes denne teoretiske tilgang giver os et andet syn på SKAT og udbyttesagen. Med denne del af analysen ønsker vi at vise, at Weicks forståelse af 
organisationer bliver afgørende for, at de konklusioner, vi drager, kan bibringe et alternativ til de eksisterende rapporters konklusioner. Her opbygger vi med afsæt i analysedesignet fra Snook en analyse af udbyttesagen med fokus på den meningsskabelse, der kan have påvirket organisationen. På henholdsvis organisations-, ledelses- og medarbejderniveau forsøger vi at finde frem til, hvilke meningsskabende elementer der kan have været afgørende for meningsskabelsen i SKAT i denne periode. Vi vil således sammenkæde disse med den handling, der fandt sted, for i sidste ende at forsøge at påvise, hvad meningsskabelsen i SKAT kan have betydet for organisationens resiliens og i sidste ende organisationens kollaps.

\section{Analyse af rapporter og medier - Når ansvaret skal placeres}

\section{De fem rapporter og undersøgelser om udbytteskandalen}

SKAT's administration af udbytteskat og refusion, Skatteministeriets Interne Revision (SIR), 24. september 2015.

Beretning til Statsrevisorerne om SKAT's forvaltning af og Skatteministeriets tilsyn med refusion af udbytteskat, Rigsrevisionen, februar 2016.

Faktuel redegørelse om administrationen af udbytterefusion i perioden 2010-2015, SKAT, af Borger- og retssikkerhedschefen i SKAT, februar 2016.

Indberetning/forholdsfortegnelse vedr. tre hjemsendte chefers rolle i forbindelse med SKAT's administration og refusion af udbytteskat i perioden 2010-2015. Rapporten er hemmeligholdt, men afrapporteret af Kammeradvokaten den 31. august 2016.

Advokatundersøgelse af forholdene vedrørende SKAT's udbetaling af udbytteskat i perioden 2010-2015, Advokatfirmaet Bech-Bruun, december 2017.

\section{a. Jagten på ansvarlige - og hierarkiets betydning}

Alle de hidtil udarbejdede rapporter om udbyttesagen lægger sig op ad det klassiske perspektivs syn på klar rollefordeling og arbejdsgange. I Rigsrevisionens beretning fra februar 2016 har konklusionerne således øje for de arbejdsopgaver, der burde være løst, og det tilsyn, der burde være ført, men ikke på de bagvedliggende grunde til, hvorfor det ikke skete, og hvorfor der ikke blev reageret. Det er i lyset af det klassiske perspektiv, at der peges på utilstrækkelig kontrol og mangelfuldt tilsyn. 
Rigsrevisionen og Rapporten fra SKATs Interne Revision (SIR) fra 2015 peger også på fejl i forretningsgange, og fokus lægges begge steder på problemer omkring placering af ansvar. SIRrapporten koncentrerer sig om medarbejdernes og ledernes rolle i SKAT, mens Rigsrevisionen fokuserer på Skatteministeriet og departementets rolle i sagen. Dog fremgår det tydeligt af begge undersøgelser, at sagen er kompleks og fejlene mange, og at de er sket på flere niveauer.

Redegørelsen fra SKAT’s Borger og Retssikkerhedschef fra februar 2016 adskiller sig fra de øvrige undersøgelser ved ikke at have fokus på personansvar, men på at skulle kortlægge og synliggøre arbejdsgange og strukturer. Den bagvedliggende præmis er dog stadig det klassiske organisationssyn, hvor klare strukturer, arbejdsgange, kontroller og arbejdsdeling er målet og løsningen. Der er i rapporten intet fokus på, hvorfor der mon ikke følges op på advarsler fra interne kontroller og opfølgninger samt diverse arbejdsgruppers konklusioner. Dette bemærkes blot som en konstatering. Rapporten viser således, at der blev begået fejl af mange mennesker på mange niveauer over mange år, men samtidig viser redegørelsen også, at personer på alle niveauer prøvede at agere ved hjælp af advarsler, kontrolanmærkninger, oprettelse af arbejdsgrupper og fx initiativer til at oplære nye medarbejdere.

Kammeradvokatens rapport udkommer i august 2016, men den bliver ikke offentliggjort. I en pressemeddelelse udsendt af Skatteministeriet fremgår det dog, at Kammeradvokatens rapport konkluderer, at der ikke er juridisk grundlag for tjenstligt forhør af de hjemsendte chefer. Da resultatet af Kammeradvokatens rapport fremstår flertydigt og ansvaret stadig blafrer i vinden, beslutter Folketinget i slutningen af 2016 at igangsætte en uvildig advokatundersøgelse af sagen. Denne undersøgelse igangsattes i februar 2017 med advokatfirmaet Bech Bruun som ansvarlige for udarbejdelsen. I kommissoriet hed det, at undersøgelsen skulle omhandle “...om og $i$ hvilket omfang der er sket fejl og forsømmelser i SKAT og Skatteministeriet, og i den forbindelse, om der er grundlag for at indlede sager om disciplinart eller ansattelsesretligt ansvar mod en eller flere embedsmand... Endelig skal advokatundersøgelsen undersøge og beskrive de faktiske omstandigheder vedrorende de siddende ministres eventuelle rolle $i$ sagen".

Igen kommer den klassiske organisationstankegang til syne i formålet med denne undersøgelse, idet den skal identificere fejl og forsømmelser, således at der kan placeres ansvar. 
Bech-Bruun-undersøgelsen blev offentliggjort i december 2017 og bekræftede det billede, som de tidligere undersøgelser også havde tegnet, nemlig at SKATs kontrol med udbytteskat havde været utilstrækkelig, at der var usikkerhed omkring ansvarsområderne på udbytteområdet, at itsystemerne ikke fungerede tilfredsstillende, og at Skatteministeriets tilsyn med SKAT i perioden med formodet svindel ikke var godt nok. Undersøgelsen vurderede endvidere - som den eneste af de hidtidige rapporter - en lang række embedsmænd i Skatteministeriet og SKAT's og deres mulige ansvar. Der blev dog ikke fundet grundlag for at indlede sager om disciplinært eller ansættelsesretligt ansvar mod de pågældende (Skm.dk).

Alle de hidtil udarbejdede rapporter og undersøgelser om sagen er således beroende på en organisationsopfattelse, der tager udgangspunkt i et klassisk, weberiansk organisationsperspektiv. Dette ses ved, at rapporternes fokus er på ansvarsplacering, hierarki og forretningsgange. Det er dog tydeligt ved gennemlæsning af rapporterne, at fejl på fejl er sket i SKAT, uden at det er let at forklare hvorfor. Med anmærkning efter anmærkning, advarsel efter advarsel, og arbejdsgruppe efter arbejdsgruppe ser det således ud til, at embedsmændene har forsøgt at gøre deres pligt og leve op til deres ansvar. Alligevel fandt svindlen sted.

Dertil kommer, at man fra politisk side iværksætter disse undersøgelser i håbet om at kunne finde skyldige i sagen. Dette sker ikke mindst på grund af presset fra offentligheden og mediernes jagt på at udpege en eller flere ansvarlige. Mediernes dækning er nemlig ligeledes centreret omkring at placere et ansvar. Medierne går ikke dybere ned i sagen om udbyttesvindlen end at forsøge at påvise, hvor højt oppe i ledelseslaget der eksisterede viden om problemerne i udbytteskat. Gennem mediernes dækning ser man også spor af medarbejdere, der føler sig frustrerede og pressede på deres arbejdsplads, og ledere, der ikke vidste, hvor de skulle sætte ind. Eller som afdelingschef i Skatteministeriet Andreas Berggreen udtaler det til Politiken: "Når hele bygningen brander, hvad er det så du skal sprøjte vand på forst?” (Politiken, 12.februar 2017)

Som vist ovenfor ser man med det klassiske organisationsperspektiv for øje SKAT som et klart hierarki, hvor der bør være tydelige forretningsgange, klare roller og ansvarsfordeling. Der er tale om specialiserede embedsmænd, der agerer loyalt og anser deres arbejde for et kald, idet de er underlagt kontrol fra deres leder. Lederne bidrager til at skabe en effektiv drift, der er med til at sikre organisationen og dermed samfundets stabilitet. SKAT som organisation er bygget op som en klassisk organisation med udgangspunkt i Webers idé om bureaukratiet som idealtype. 
Set i dette perspektiv bør det således også være muligt at placere et ansvar for udbytteskandalen. På trods af de gennemgående og grundige undersøgelser er det dog endnu ikke lykkedes nogle af rapporterne at få placeret et endeligt og juridisk ansvar for svindlen. Til dette har sagen vist sig for indviklet og kompleks.

Således kan det være svært ud fra det klassiske perspektiv at pege på, hvor skylden kan placeres, for hvad hvis alle har gjort deres arbejde så godt som muligt, og svindlen alligevel fandt sted hvem har så skylden?

Rapporternes fokus går således på ansvarsplacering, fra mikroniveau med ansvarsvurdering af enkelte medarbejdere til makroniveau med fokus på forholdet mellem SKAT og skatteministeriet. De kigger dog ikke på samspillet og relationerne, hvor meningen skabes. De undersøger og blotlægger på detaljeniveau, hvem der vidste hvad, men går ikke dybere ind i, hvordan det kunne ske, at der ikke blev handlet. Baseret på ovenstående gennemgang af rapporter og medier ser det rent faktisk ud som om, at alle vidste det sejlede i SKAT, og at alle desuden troede, at de gjorde det, de kunne. Alligevel gjorde ingen åbenbart nok.

Hvis vi derimod anskuer SKAT som et løst koblet system, åbner der sig forklaringer, der fokuserer på, hvordan meningen skabes i relationer og i handlinger.

\section{E. Analyse Meningsskabelse i SKAT - Mening på flere niveauer}

\section{Mening på medarbejderniveau}

"Vi var jo ved at segne, vi var ganske få mennesker. Alle blev fyret, alle blev sendt vak, alt blev ophavet, alt blev nedlagt" (Ansat i SKAT, Milliardkuppet, DR).

I 2012, hvor udbyttesagen starter, har et væld af omstruktureringer og effektiviseringer over en lang årrække sat deres præg på SKAT. Fx er der i perioden 2007 til 2017 reduceret i medarbejderstaben med over 2.000 årsværk, og siden skattereformen i 2005 har skatteområdet været udsat for talrige omstruktureringer, herunder fusioner, nye strategiske fokusområder og markante ændringer i medarbejdersammensætning og faglighed. 
De omfattende omstruktureringer er en del af bagtæppet, når vi i Weicks optik beskuer, hvor SKAT var ved at bevæge sig hen i tiden omkring udbytteskandalen. De mange ændringer og fyringer, som finder sted i organisationen, påvirker de sociale processer. Medarbejdere, der arbejder med de samme opgaver, områder eller i samme kontor, kender i 2012 ikke nødvendigvis hinanden særlig godt.

En tillidsrepræsentant i SKAT, udtaler i 'Skeletterne i Skat': “Vi havde en leder indtil 1.januar i Svendborg, noget der hed 'Vejledning'. Den blev så splittet op 1. januar. Så fik jeg så en leder, og han sad dels i Middelfart og dels $i$ Odense, så omkring 1. april, så blev vi igen delt op. Nogen kom til noget, der hed 'Vejledning' i Arhus, nogen kom til 'Kunde-person' som lå i Svendborg-Odense-Middelfart, der havde vi en leder $i$ en måned, så fikjeg en ny leder, der sad $i$ Ribe. Og her fra 1.8. har jeg så fået en leder, der sidder $i$ Horsens" (Skeletterne i SKAT, DR, 2016).

Omstruktureringerne og effektiviseringerne i SKAT er således en grundlæggende præmis for de meningsskabende sekvenser, medarbejderne i SKAT tog del i. Da sociale processer er et af meningsskabelsens syv elementer, har det betydning for medarbejdernes meningsskabelse, at de måske hverken kender deres nærmeste leder eller deres kolleger særlig godt. Tilliden internt i organisationen og på udbytteområdet er således under pres.

På udbytteområdet sker der også nedskæringer og omstruktureringer. Borger- og retssikkerhedschefen fremlægger i sin rapport en detaljeret gennemgang af de omstruktureringer, der har været på området. Opgaveløsningen med refusion af udbytteskat fra 2010-12 var fx placeret i Ballerup, mens den ledelsesmæssigt var forankret i Region Midtjylland, med afdelingen 'Borger- og virksomhed' som procesejer. Fra 2013 lå udbytteadministrationen derimod under forretningsområdet 'Inddrivelse' i afdelingen 'Betaling og Regnskab'. Her lå refusionsopgaven placeret i enheden 'Regnskab 2' fra januar 2013 - april 2013. Derefter blev den placeret i enheden 'DMO/DMS’ fra maj 2013 - juni 2013, hvorefter den i juli 2013 endelig blev placeret i enheden ‘SAP38 - Høje Taastrup’. Ansvaret for området var endvidere, som tidligere beskrevet, placeret i hele fire forskellige direktørområder i tiden fra 2013-2015 (Faktuel redegørelse om administration af udbytterefusion i perioden 2010-2015, Borger og retssikkerhedschefen, februar 2016).

Er man derfor forvirret efter at have læst ovennævnte gennemgang af placeringen af området for udbytteskat, skal man forestille sig, hvordan det var at være medarbejder. 


\section{a. Faglighed og identitet}

Identitet er ifølge Weick også en del af meningsskabelsesprocessen, og den ændres, hvis individets identitetsopfattelse ændres. I SKAT var der et stort fokus på faglighed, og organisationen havde udover mange specialiserede medarbejdere også mange medarbejdere med høj anciennitet. I 2007 skete der et bevidst skift i SKATs strategiske fokus, som bevirkede, at organisationen gik fra at være en kontrolvirksomhed til at være en udadvendt serviceorganisation, der er til for borgerne. I resultatkontrakten mellem SKAT og Skatteministeriet fra 2007 oplistes en række mål, hvor kundeservice er i fokus. I kontrakten står fx beskrevet at: "SKAT ønsker løbende at følge op på den service, som leveres til kunderne. Kundetilfredshed er derfor et nøglebegreb, som skal tankes ind $i$ alt, hvad SKAT foretager sig." Skatteborgerne bliver dermed i SKATs optik til "kunder", og fokus er dermed kundetilfredshed frem for kontrol af skat.

Dette har ifølge Karen Boll, der har skrevet ph.d. om SKAT og er tidligere ansat i SKAT også indflydelse på medarbejdersammensætningen: "De nye medarbejdere, der kommer frem $i$ skattecentrene. Det er en, der er mere serviceorienteret, som skal kunne servicere borgerne, som skulle kunne vejlede borgerne, som skal vare god til at lave projektarbejde, lave projektbeskrivelser, leverancer og succesmål... Den gamle skattemedarbejder, det er en kontrolmedarbejder. Det er en, der kan momsloven og skatteloven og juraen og det tekniske og sådan lidt af en fagnørd" (Skeletterne i SKAT, DR, 2016)).

SKAT's erfarne medarbejdere skal efter 2007 skifte fokus i tilgangen til deres arbejde, hvilket en tidligere medarbejder kommenterer således: "Ja, det skulle vare den sunde udvikling, ikke. At gå fra kun at vare en stivstikker embedsmandsbureaukrat, hvor man hele tiden 'controller', hvor man havde mistro til borgeren og virksomhederne og så til at gå til at sige: Jamen hvad kunne vi egentlig gøre for borgerne og virksomhederne? [...] nogen steder, så gik det jo over gevind, så gik det jo over til: 'Nå, men når jeg ikke må lave kontrol, så skal jeg nok 100\% lave service. Og ikke lave noget kontrol” (Skeletterne i SKAT, DR, 2016)).

Alene det at bruge termen kunder er noget, medarbejderne i SKAT hæfter sig ved: “... vi grinte lidt og sagde, hvem fanden vil vare kunde i SKAT. Det vil man helst vare frifor, ikke. Nå, men det var hele den der terminologi... du skal vare en servicevirksomhed, du skal ikke vare en kontrolvirksomhed mere”.

Ledelsens strategiske fokus på kundeservice og opsætningen af mål i forhold til kundetilfredshed er således afgørende, ikke alene for medarbejdernes identitet, men også for hvilke ledetråde, 
medarbejderne forstørrer, og dermed hvilken mening de skaber. En medarbejder, der håndterer udbytterefusion, vil ikke have fokus på kontrollen af refusionen, men i stedet på udbetalingen, og den hurtige forretningsgang, som vil betyde en god service.

I perioden, hvor svindlen finder sted, har medarbejdernes selvopfattelse påvirket deres meningsskabelse. Deres identitet som specialiserede skattemedarbejdere er udfordret, og der er mangel på tillid medarbejdere og ledere imellem.

\section{b. Tab af tillid og tegn på apati}

I programmet 'Skeletterne i Skat' (DR, 2016) udtaler flere anonyme skattemedarbejdere sig om deres arbejdssituation. De udtrykker frustration og virker nærmest opgivende i deres tilgang til deres arbejde: "Da jeg kom ind til SKAT i 2005, der var vi 40 i afdelingen, fem år efter var vi otte. Til samme arbejdsbyrde. Folk bliver mere og mere frustrerede. Man kan jo selv se, at man ikke når det arbejde, man egentlig skulle. "Jeg har oplevet, at min kollegaer er blevet flyttet til ejendomsvurderinger, betalinger og kundeservice. Det har blot betydet, at vi har skulle arbejde endnu hårdere". "Vi kigger bare på hinanden og tanker: det er fuldstandig af lave. Der er ingen, der ved, hvad hinanden foretager sig". "Vi forventer, at der kommer flere skandaler. Vi er vant til dem. Bare vent og se, hvad der kommer neste gang”.

De fire udsagn har det tilfælles, at de understreger en følelse af dekobling. Det virker, som om at de qua den stressede og turbulente situation ikke kan skabe mening i deres arbejdsopgaver længere. Den mening, de skaber retrospektivt, bygger på en erfaring af kaos, og skabes på baggrund af ledetråde funderet i turbulens. Man fornemmer næsten en følelse af apati, der spreder sig.

\section{Mening på ledelsesniveau}

De meningsskabende sekvenser, der har påvirket meningsskabelsen på ledelsesniveauet, har ligeledes været præget af de mange omstruktureringer og effektiviseringer. Der er desuden blevet stillet nye krav til ledelsen i SKAT, idet ledelse er gået fra at være orienteret mod en stærk faglighed og fokus på kontrol til at fokusere på generaliseret viden om ledelse med udgangspunkt i en servicedagsorden, hvor det ledende paradigme er kundefokus. Dertil kommer, at de mange ændringer og fyringer har påvirket de sociale processer, således at chefer ikke nødvendigvis kender deres personale, endsige er fysisk placeret sammen med dem. Meget tyder endda på, at det for den enkelte leder kneb med at kende eget ansvarsområde. Set i lyset af, at meningsskabelse 
sker bagudrettet og på baggrund af erfaringer, har disse forhold stor indvirkning på den mening, lederne har haft mulighed for at skabe.

\section{a. Udskiftninger, omorganiseringer og faglighed}

På ledelsesniveau var der også stor udskiftning, dette hele vejen op til departementschefen. I marts 2012 bliver Peter Loft hjemsendt som departementschef efter over 30 års ansættelse i Skatteministeriet, og Jens Brøchner tiltræder i maj 2012 som ny departementschef. Brøchner er uddannet cand.polit og har en fortid som afdelingschef i Finansministeriet og som koncerndirektør i ATP, mens han ingen umiddelbar erfaring har med skatteområdet. I december samme år ansættes Andreas Berggreen som afdelingschef i Skatteministeriets departement. Han har en fortid som senior manager i Deloitte og i Finansministeriets departement. Desuden får SKAT ny direktør i slutningen af 2012, da cand.polit., Jesper Rønnow Simonsen, ansættes som direktør for SKAT. Han kommer direkte fra en stilling som økonomidirektør i Københavns Kommunes Børne- og Ungdomsforvaltning.

Det er ikke kun i topledelsen, at udskiftningerne og skiftet væk fra fagledelse sker. Tidligere departementschef, Peter Loft, udtaler: “Altså, det er jo ikke kun departementschefen eller told- $\mathbb{E}$ skattedirektoren [...], der bliver udskiftet, det var stort set hele ledelsen, der røg ud der i 2012. Og det har jo varet et eller andet: 'nu gider vi ikke at høre på de der fagnorder langere'” (Tidl. Departementschef Skatteministeriet Peter Loft, 13. september 2017). Dette bemærker også en tidligere medarbejder på ledelsesniveau: "jamen lige så snart en leder havde fået forstand på sit område, så blev vedkommende flyttet, fordi ledelse var nu fagligheden, og det var ledelse, man skulle. Og det gik slet slet ikke.” (Skeletterne i SKAT, DR, 2016).

En yderligere indikation på, at de mange udskiftninger i ledelsen og blandt de ansatte påvirkede vidensniveauet, ses fx i Skatteministerens svar til statsrevisorernes rapport: "Til de konkrete indikationer bemarkes, at de vedrorer ganske forskellige forhold på udbytteområdet og ikke alle peger $i$ samme retning, ligesom vidensniveauet herom desvarre ikke blev akkumuleret i Skatteministeriet over tid." (Ministerredegørelse til statsrevisorernes beretning nr. 11/2015 om SKATs forvaltning af og Skatteministeriet tilsyn med refusion af udbetaling af udbytteskat, Skatteministeriet, 4. maj 2016). 


\section{b. Service, målopfyldelse og ledetråde}

Som beskrevet blev der i 2007 formuleret et mål om forøget fokus på kundeservice og måling af kundetilfredshed, som skulle tænkes ind i alt, hvad SKAT foretog sig (Kundeservicestrategi 2014 Kunden i centrum, skatten i balance). Dette mål afspejles fx i Jesper Rønnow Simonsens resultatkontrakt fra 2015 (Resultatlønskontrakt Jesper Rønnow Simonsen, 2015; SKAT - Mål 4 Løbende måling af kundetilfredshed) og er en afgørende ramme for de meningsskabende sekvenser, der førte til handling på ledelsesniveau.

Servicemålene kan have været de ledetråde, direktøren forstørrede mest op, og dermed fik kundeservice en central betydning for hans meningsskabelse og blev afgørende for, at der fx ikke blev opstillet KPI'er på kontrol af udbytterefusion. Inden for refusionsområdet var der ikke, jf. Borger og Retssikkerhedschefens rapport, “...benyttet interne kontrolpunkter for den enhed $i$ Inddrivelse, som varetog udbytteadministrationen" (Faktuel redegørelse om administrationen af udbytterefusion i perioden 2010-2015, februar 2016) og på trods af 36 revisionsanmærkninger i perioden 2012-15 blev der ikke reageret. Ledelsen prioriterede i stedet servicedagsordenen og bestilte i 2014 en kundeservicestrategi ("Kunden i centrum, skatten i balance”). Netop på dette tidspunkt var svindlen med udbytteskat i fuld gang.

På denne måde kan servicedagsordenen siges at have påvirket handlingen og meningsskabelsen på ledelsesniveauet, ligesom det påvirkede meningsskabelsen på medarbejderniveauet. Det vil sige, at man på ledelsesniveauet foretog tilvalg i forhold til denne dagsorden, mens man fravalgte "kontrol-dagsordenen” på refusionsområdet.

\section{c. Plausibilitet og akkuratesse}

I Weicks optik er det væsentligt at være opmærksom på, at de forstyrrelser, som igangsætter ny meningsskabelse, kan udvikle sig uheldigt. Det faktum, at meningsskabelse sker på baggrund af plausibilitet og ikke akkuratesse, samt at det altid sker retrospektivt, påvirker den mening, ledelsen skaber. Før 2015 havde man aldrig før hørt om skattesvindel for milliarder, ej heller om svindel med refusion af udbytteskat. Ingen medier havde skrevet om det, og det var ikke i politikernes søgelys. Så det var på dette tidspunkt ikke en plausibel forklaring i SKAT, at det netop var dette, der var ved at ske. 
I stedet var 'omverdenens holdning' til SKAT et af de helt store strategiske omdrejningspunkter. Dertil kommer, at selvom det retrospektivt står lysende klart, at man skulle have handlet anderledes i forhold til udbytteskatteområdet, så var det ikke her, man fokuserede. Som afdelingschef i Skatteministeriet, Andreas Berggreen, udtrykker det: "Men der var ikke en bevidsthed $i$ hovedet på os om, at der var et konkret problem, for så ville man selvfølgelig have handlet helt anderledes. Så ville man konkret have smakket låget på statskassen i.”(Politiken, 12. februar 2017).

Man kiggede altså slet ikke i retning af svindel, og da der ikke var en bevidsthed herom, ville anderledes handling kræve en handling, der ikke gav mening på ledelsesniveau. Det, der til gengæld gav mening, var nedsættelse af arbejdsgrupper.

\section{d. Nedsattelse af arbejdsgrupper som meningsskabende sekvenser}

Udvandingen af den skattefaglige faglighed betød, at der blev færre erfarne skattemedarbejdere. Der blev nu til gengæld opbygget en faglighed i forhold til service og ledelse. Det vil sige, at nye medarbejdere og ledere var nogle, der skulle kunne servicere og vejlede borgerne, vare gode til projektarbejde og projektbeskrivelser. Og på ledelsesniveauet skulle de derudover have fokus på leverancer og succesmål. Der blev i perioden 2010-15 nedsat hele ni forskellige arbejdsgrupper, der alle havde til opgave at udarbejde analyser, der omhandlede udbytteskatteområdet. Udover de arbejdsgrupper, der allerede er beskrevet, drejer det sig om en række arbejdsgrupper, hvis formål er beskrevet i nedenstående:

- Arbejdsgruppe, der fra 2010-13 skulle arbejde inden for rammerne af TRACE-projektet i OECD-regi (TRACE Implementation Package for the Adoption of the Authorized Intermediary System - A Standardized System for Effective Withholding Tax Relief Procedures for Cross-Border Portfolio Income, 23. januar 2013)

- Arbejdsgruppe, fra juli 2013, der blev benævnt 'Kontrol I'. Denne arbejdsgruppe fik deadline 31.12. 2013, men deadline blev udskudt til foråret 2014. Alligevel blev arbejdet aldrig færdiggjort

- Arbejdsgruppe, der blev nedsat i 4. kvartal 2014. Den blev nedlagt kort tid efter med henvisning til TRACE-arbejdsgruppens arbejde. TRACE-arbejdsgruppen var dog, som vist ovenfor, allerede blevet nedlagt i begyndelsen af 2013 
Ledelsen i SKAT greb til handling ved, at nedsætte arbejdsgrupper og få udarbejdet rapporter. Nedsættelse af arbejdsgrupper blev således bestemmende for ledelsesniveauets meningsskabende handlinger.

Af følgende citat ses, at afdelingschef, Andreas Berggreen, mener, at arbejdsgrupperne og undersøgelserne havde en eksistensberettigelse, selvom udbyttesvindlen for 12,3 mia. fandt sted, og på trods af alle rapporterne og deres advarsler: "Da udbytteskattesagen ramte, var vi jo på grund af denne analyse (Turnusanalyse af betalings- og regnskabsområdet, rapport udarbejdet af Deloitte, juni 2015) langt bedre $i$ stand til at forstå, hvad det egentlig var, der var sket. For det var jo udtryk for, at den risiko, som er beskrevet her, rent faktisk har materialiseret sig. Det er selvfolgelig utroligt argerligt, for hvis man havde implementeret det her i 2012, så må man gå ud fra, at det var blevet fanget lang tid for. Men $i$ mit hoved, så synes jeg, at den analyse afspejler, at vi som departement $i$ virkeligheden handlede meget aktivt på de risici, som var identificeret over for os, og prøvede at gore noget rigtigt ved dem"(Politiken, 12. februar 2017). Berggreen udtrykker dermed, at de i departementet havde handlet aktivt på de identificerede risici og at man prøvede at gøre noget rigtigt ved dem. Skønt han dog er ærgerlig over, at de ikke implementerede analysens anbefalinger noget før.

Ledelsen i SKAT har dermed tyet til meningsskabelse gennem handling, der ikke giver mening. Handlingen at nedsatte arbejdsgrupper giver ikke mening, da de mange rapporter, der bliver udarbejdet, øjensynligt blot medfører beslutninger om nye undersøgelser, arbejdsgrupper og rapporter, alt imens de ingen reelle ændringer medfører. Således fremstår ledelsesniveauet i virkeligheden som handlingslammede i stedet for handlende.

\section{Mening på organisationsniveau}

De til- og fravalg, der blev taget i SKAT på både ledelses- og medarbejderniveau, er dog præget af meningsskabende elementer på organisationsniveau. Her sætter magtforholdet mellem Skatteministeriet og Finansministeriet en afgørende ramme for bl.a. de ansættelser, der skete selv på topniveau i organisationen.

\section{a. Forholdet til Finansen}

Forholdet mellem Skatteministeriet og Finansministeriet kan have en underliggende betydning for de begivenheder, der endte med at påvirke meningsskabelsen i SKAT op til udbytteskandalen. Finansministeriet, spiller en afgørende rolle, for den finanslov, der vedtages i 2006, hvor det 
besluttes, at SKAT skal spare 40\% på 6 år. Vedtagelsen af denne finanslov skal ses i lyset af Finansministeriets magt i forhold til de øvrige ministerier, da ministeriet siden Mogens Lykketoft og Anders Eldrup reformerede det i 1990’erne, har siddet på en stor del af magten i dansk politik.

Finansministeren sidder således som fast formand i det magtfulde Ø-udvalg, mens departementschefen i Finansministeriet sidder for bordenden for det Forberedende udvalg, også kaldet Styregruppen. En magtfordeling, der stadig eksisterer i dag, og som har spillet en afgørende rolle for besparelserne i SKAT.

I Skatteministeriet er man godt klar over magtforholdet. En medarbejder, der er ansat i Skatteministeriet, mens Peter Loft stadig er departementschef, udtaler således: "I nogle perioder, så lå Skatteministeriet og Finansministeriet jo i krig med hinanden, både politisk og dermed også på embedsmandsniveau. Så der var jo nogen af de der losninger, som ikke var serligt gode for Skatteministeriet. Som blev presset igennem af Finansministeriet, og som ikke var sarligt fagligt velbegrundede [...]” (Tidl. Departementschef Skatteministeriet Peter Loft, 13. september 2017).

På baggrund af Lykketofts og Eldrups reformering af Finansministeriet kan det således være svært for ressortministrene at få ørenlyd. Det er således sigende, at der har været så hyppig udskiftning på ministerstolen i Skatteministeriet med otte ministre på syv år, imens besparelser og effektiviseringer er rullet hen over SKAT.

Med indførelsen af det Forberedende udvalg i 1990’erne får embedsmændenes og departementschefernes rolle en større betydning. Som Anders Eldrup selv udtaler det i et interview til Information: "Det giver naturligvis også departementscheferne mulighed for i højere grad at satte deres fingeraftryk, nu hvor de er med til at forberede sagerne” I samme artikel fremgår det således også, hvordan oprettelsen af de to udvalg medførte en slags opdragelse af embedsapparatet: “Netop departementschefernes ogede indflydelse har haft betydning for den opdragelse af embedsapparatet, som Anders Eldrup gennemforte $i$ tat samarbejde med Mogens Lykketoft. En opdragelse, som trakker tråde til $i$ dag, hvor embedsfolk stadig forer principperne videre. Hvor samarbejde på tvars af ministerierne bliver koordineret af Finansministeriet - med Statsministeriet på sidelinjen. Og hvor en embedsmand narmest pr. automatik orienterer sig mod både Finansministeriet, Statsministeriet og sit eget ministerium.” 
Det bliver altså fra 1990’erne og frem helt naturligt, at departementscheferne i de øvrige ministerier begynder at orientere sig mod Finansministeriet, da deres forhold til departementschefen i Finansministeriet og deres indsigt i ministeriets regnemetoder kan få stor betydning for deres mulighed for at få sager gennemført, eller modstå besparelser.

Op igennem 2010’erne ændres fokus på ledelse i SKAT sig som vist, fra at være en skattefaglig ledelse til at blive en mere generaliseret ledelsesform. Dette sker ved løbende udskiftning i ledelsesniveauet, hvoraf det største skifte sker ved valget af den nye departementschef i 2012. Jens Brøchner ansættes gennem regeringens ansættelsesudvalg, som udover statsministeren også består af bl.a. finansministeren. Han har ingen umiddelbar skattemæssig erfaring, men han har til gengæld erfaringer med sig fra bl.a. Finansministeriet. Brøchner ansætter efter sin tiltræden bl.a. Andreas Berggreen, der, som nævnt også har erfaring fra Finansministeriet samt konsulenthuset Deloitte. Skatteministeriet er således et eksempel på, hvordan udskiftningen på embedsmandsniveau viser en orientering mod Finansministeriet, og et skifte mod en mere generel ledelsesform og en mindre faglig ledelse, noget der som nævnt i artiklen måske kan vise sig at være en mere generel tendens. Blandt de nuværende departementschefer har mere end hver anden således erfaring fra Finansministeriet.

Finansministeriets rolle i det, der skete i SKAT, er altså ikke til at tage fejl af, da det langt hen ad vejen er her fra, at presset for besparelser i SKAT stammer. Det faktum, at ministrene i Skatteministeriet i de sidste mange år ikke har siddet på området længe ad gangen, har yderligere medvirket til, at skævheden i magtforholdet mellem de to ministerier er blevet mere markant. Med Peter Lofts afgang mistede Skatteministeriet en fagligt funderet chef, og med Jens Brøchner ansattes i stedet en, der har indsigt i og forståelse for Finansministeriets regnemetoder og tankegang.

I Weicks optik vil bevægelsen, som SKAT er i, da udbyttesvindlen finder sted, således være præget af dette overordnede paradigmeskift fra fokus på fag-faglighed og kontrol til fokus på service ogledelsesfaglighed. Paradigmeskiftet kan til dels være afstedkommet af Finansministeriets mange år med betydelig magt i forhold til de øvrige ministerier. Det ulige magtforhold har sat sit præg på centraladministrationen og embedsværket og påvirker den meningsskabelse, der sker her, hvor flere og flere departementschefer og topembedsmænd ansættes med erfaring fra Finansministeriet i bagagen. 
Dette er således en del af rammen for de meningsskabende sekvenser, der finder sted i SKAT i tiden op til og omkring at udbyttesvindlen. Det er i dette lys, at meningssskabelsen hos både medarbejdere og ledere i SKAT er sket. Magtforholdet mellem ministerierne har været medvirkende til, at en ny ledelse med et mindre fagligt fokus er blevet realiteten i SKAT. Den nye ledelse er opvokset med Finansministeriets regnemetoder, og da meningsskabelse sker retrospektivt, forstørrer ledelsen dermed de ledetråde, der omhandler effektiviseringer.

Med det forstørrede fokus på økonomiske stramninger, baseret på diverse konsulentrapporter, lægges kimen til, at udbyttesvindlen kunne ske.

\section{b. Konsulenthuse i kulissen}

En anden aktør, der spiller en væsentlig rolle i forbindelse med skandalen i SKAT, er konsulenthusene, og deres rapporter og regnemetoder. Dette virker som et oplagt sted at vende sit blik, i og med at målet om at spare 40\% i SKAT, som blev vedtaget i Finansloven i 2006, var baseret på tal fra en konsulentrapport, udarbejdet af Boston Consulting Group i maj 2005. Potentialet ved en fusioneret skatteadministration, rapport udarbejdet af Boston Consulting Group, maj 2005). Endvidere er det konsulenthuset Mckinsey, der i december 2012 laver en rapport om det fulde effektiviseringspotentiale i SKAT, som følge af, at de oprindelige mål fra 2006 ikke er opnået (Analyse af Skatteministeriet, rapport udarbejdet af Mckinsey \& company, december 2012). Mckinsey-Rapporten bestilles i marts 2012 af Skatteministeriet og Finansministeriet, på baggrund af en beslutning taget i regeringens økonomiudvalg.

De to rapporter og deres resultater med bud på effektiviseringer spiller således en afgørende rolle for de effektiviseringer og omorganiseringer, der fra 2005 ruller ind over SKAT. Konsulenthusene gemmer sig således i kulissen bag flere af de store strategiske planer, der ender med at få betydning for SKAT. Og selvom flere medier skriver om konsulenthusenes rolle i udbytteskandalen, er der i de allerede gennemførte undersøgelser om udbyttesagen ikke fokus på dette. Baggrunden for, at undersøgelserne ikke dykker ned i konsulenthusenes udregningsmetoder, kan være, at deres fokus er på at placere ansvar. Konsulenthusene er som udgangspunkt ansvarsfrie. Når de har udarbejdet og afleveret deres rapporter, er deres job så at sige overstået, og de kan ikke drages til ansvar for sagens videre forløb, eller om gevinstrealiseringen reelt er opnåelig. 
Set i meningsskabelsesperspektivet kan brugen af konsulenter i det offentlige anskues i forhold til flere af Weicks meningsskabende elementer. Når man som leder gør brug af managementkonsulenter til at identificere effektiviseringer og udarbejde strategier, kan det anskues som værende retrospektiv meningsskabelse. Det er efterhånden blevet kutyme i staten at gøre brug af managementkonsulenter, når der skal laves strategier eller effektiviseres i det offentlige. Således var forbruget på konsulentydelser i Staten i 2012 på 3.622 mio. kr. Når det på denne måde er blevet helt alment at basere strategier på konsulentrapporters udregninger, er det retrospektiv meningsskabelse. Hvis det var det, man gjorde sidste gang og forrige gang, en strategi skulle udarbejdes, vil det således også være oplagt næste gang. Dette ses også i forbindelse med Karsten Lauritzens redningsplan for SKAT, der fremlægges i august 2016, hvor der er afsat 500 mio. kr. til en konsulentanalyse af alle områder i SKAT.

Endvidere er der tale om det sociale element af meningsskabelse, når der bliver bestilt rapporter fra konsulenthuse. For når det er det, alle de andre ministerier gør, og som det magtfulde Finansministerium foretrækker og lægger op til, så bliver det endnu mere alment at gøre det. Det er således også en del af en social proces. Der er blevet skabt en mening på øverste niveau af embedsværket om, at konsulentrapporterne er vigtige og rigtige og derfor gode at basere beslutninger på. Da denne del af embedsværket endvidere ofte selv er opdraget med samme tankegang for øje, giver denne tankegang både retrospektivt og socialt mening for dem. De forstørrer dermed de ledetråde, de kan genkende i de økonomiske beregninger, som de kan forstå. Den faglige kritik giver dermed ikke mening for dem, fordi de ikke kan genkende ledetrådene og ikke forstår dem. Endvidere er det ikke sikkert, at politikerne forholder sig til konsulenternes beregninger. Hvis det virker plausibelt, at konsulenterne har ret, har de det nok. Meningsskabelse sker ud fra plausibilitet og ikke akkuratesse.

\section{c. New Public Management (NPM)}

Resultatkontrakter og målstyring har holdt deres indtog i SKAT. Der henvises i udtalelser fra medarbejdere til KPI'er og New Public Management-bølgen. NPM opstod i 1980'erne som en kritik af bureaukratiet med udgangspunkt i, at styringen haltede på grund af bureaukratiske processer.

NPM tilbød således at genopfinde styringen gennem ti principper for entreprenant governance. Med disse kunne regeringer fremme konkurrencen mellem serviceleverandører og myndiggøre 
(empower) borgerne ved at flytte kontrollen fra bureaukratiet til nærområdet. (Vikkelsø og Kjær, 2014, s. 40). Regeringer kunne ved hjælp af NPM fx "måle deres instansers performance ved at fokusere på resultater”. Der kom således med NPM et fokus på mål i stedet for regler og regulativer. Og det blev gennem dette perspektiv vigtigt at forstå borgerne eller klienterne som brugere eller kunder (Vikkelsø og Kjær, 2014, s. 40). I NPM foretrækkes markedsmekanismer frem for forvaltningsmekanismer (Ibid).

NPM har dermed fostret idéen om, at offentlige organisationer skal fungere som private virksomheder, hvilket indebærer en udviskning af forskellen mellem administration (overordnet styring) og management (tilvejebringelse af tjenester til kunder) (Vikkelsø og Kjær, 2014, s. 41).

NPM holdt sit indtog i den offentlige forvaltning i løbet af 80’erne, og fik således også stor betydning for SKAT og Skatteministeriet. Som Karen Boll udtaler det: "Den nye styreform man så går over til her fra 2007 og frem, der har man effektmål, hvor man kigger på nogle mere overordnede mål, der ligger uden for den produktion SKAT har. Fx at man skal højne regelefterlevelsen hos borgere og virksomheder, og at man skal have en høj kundetilfredshed. Det er en del af den her New Public Management-bølge, som er kommet indenfor den offentlige sektor" (Skeletterne i SKAT, DR, 2016).

Et udsagn SF'eren, Lisbeth Beck Poulsen nikker genkendende til: “Vi har fået en New Public Management-kultur, hvor konsulentrapporter og Finansministeriet høster, for man overhovedet ser gevinsterne af noget som helst. Man salger bjørnen årevis, for den er skudt” (Skeletterne i SKAT, DR, 2016).

NPM synes dermed at være blevet den fremherskende måde at drive SKAT og Skatteministeriet på. I et meningsskabelsesperspektiv bliver den dagsorden, NPM sætter, meningsskabende i en kontinuerlig proces på det organisatoriske niveau. Dertil kommer, at de ti NPM-principper bliver til de ledetråde, der kontinuerligt forstørres i organisationen.

Som tidligere vist materialiserede NPM-tankegangen sig i SKAT gennem blandt andet direktørens resultatkontrakt, samt i KPI’er og effektmål for ledere på de øvrige niveauer.

Karen Boll udbygger sit udsagn om NPM i SKAT med følgende: "Og New Public Management er ligesom en ide om, at man har set bureaukratiet eller den offentlige sektor som ineffektiv, som 
omkostningstung, og som havende brug for nogen reformer for ligesom at komme lidt mere op i gear" (Skeletterne i SKAT, DR, 2016). Resultatkontrakter ses således som et håndgribeligt tegn på NPM-dagsordenens indvirkning på SKAT, og NPM synes dermed at blive en del af den mening, der som beskrevet ovenfor skabes i SKAT.

Den tidligere departementschef udtaler om NPM's påvirkning af udbytteområdet: “Og så har man altså fjernet enhver form for kontrol, formentlig - igen gatvark - fordi de ressourcer kunne bruges på steder, hvor man blev målt $i$ henhold til denne her NPM-kontrakt. Det er jo det, det skaber. Altså du får jo forvridninger, når du siger, vi lagger meget vagt på brugertilfredshed, I skal kontrollere cykelslanger, men der står ikke spor om, at I skal kontrollere udbytteskat-refusioner, formentlig fordi ingen vidste, at der var noget, der hed sådan. Jamen så siger de, jeg kan få nogle flere point, eller vi kan gøre folk glade, eller vi kan få ros af departementschefen, hvis vi bruger flere ressourcer her" (Tidl. Departementschef Skatteministeriet Peter Loft, 13. september 2017.). Således stiller den tidligere departementschef spørgsmålstegn ved det rigtige i at tælle point i forbindelse med målopfyldelse og resultatkontrakter samt fokus på kundetilfredshed. Dermed kan der igen peges på, at NPMdagsordenen på organisationsniveau var med til at forstørre de meningsskabende ledetråde, der havde at gøre med brugertilfredshed og 'at gøre folk glade’.

Karen Boll stiller sig ligeledes tvivlende overfor, om NPM er den rette styringstænkning for SKAT: "Der mener jeg klart, at noget af det der traditionelle bureaukrati, som man ellers har skaldt ud, er måske noget af det SKAT skal finde tilbage til, fordi det er jo det der gør, at vi har en retferdig og effektiv skatteforvaltning" (Skeletterne i SKAT, DR, 2016). Dermed udtrykkes en bekymring for, at de forstørrede ledetråde vedrørende brugertilfredshed, service og omverdenen har skubbet en effektiv og retferdig skatteforvaltning i baggrunden.

Således kan det siges, at forstørrelsen af de ledetråde, som NPM-tænkningen har ført med sig, har påvirket mønstrene af meningsskabende sekvenser i SKAT. Og yderligere har det som ovenfor beskrevet haft konsekvenser på organisationens identitet og den handling, der foregår på dette niveau.

\section{d. Politiske visioner}

Skatteområdet har været præget af store organisatoriske og strukturelle ændringer.

Strukturreformen, der blev præsenteret i sommeren 2004 af Fogh-regeringen, kom, til at sætte et 
markant præg på den udvikling, der er sket med SKAT de seneste 13 år. Visionerne for reformen var store, da Anders Fogh Rasmussen præsenterede den ved et pressemøde i 2004: "Jeg vil $i$ dag prasentere de storste forandringer vi har oplevet og vil opleve $i$ det danske velfardssamfund $i$ en generation eller to" (Anders Fogh Andersen, pressemøde, 2004).

Med visionen "Det nye Danmark: En enkel og mere effektiv skatteadministration - tat på borgerne " Ønskede regeringen, således at: "gennemfore en gennemgribende reform af den kommunale struktur. Den offentlige sektor skal moderniseres, sa den lever op til fremtidens udfordringer med hensyn til narhed, kvalitet og effektivitet. Den offentlige sektor skal vare enkel og med farre niveauer.

Strukturreformen indeholdt tre forskellige spor, hvoraf det ene spor indebar en ny fordeling af opgaverne mellem kommuner, regioner og staten. Et eksempel på den ændrede opgavefordeling mellem stat og kommune er sammenlægningen af de kommunale ligningsopgaver, som medførte, at den statslige organisation SKAT siden 2005 har varetaget den samlede skatteligning og skatteopkrævning.

Strukturreformen udspringer af den daværende VK-regerings politiske visioner for den offentlige sektors struktur. Da den bliver præsenteret i 2004, er den således et resultat af Statsminister Anders Foghs politiske visioner om at effektivisere det offentlige qua den neo-liberalistiske tanke. Grundlæggende for denne tanke er således tre forhold: 1. liberalisering af priskontrol og af kapitalmarkeder, samt fjernelse af handelsbarrierer. 2. Statens tilbagetrækning fra økonomien gennem deregulering, privatisering og outsourcing og 3. Anvendelse af pengepolitikken til at kontrollerer pengeudbuddet, sikre mod høj inflation og styre statsunderskud (Pedersen, 2011, s. 25). Endvidere indgår idéen om minimalstaten, som en del af den neoliberale tankegang, hvor staten kun skal skabe de allervigtigste rammer for markedet (Ibid). Neoliberalismen bygger således på kapitalismens finansliggørelse i 1980’erne, hvor finanskapitalen forandres fra at være en B-spiller, til at være en A-spiller, og med sin indbyggede kritik af velfærdsstaten skabte især Ronald Reagan og Margaret Thatcher dens politiske grobund (Pedersen, 2011, s. 25).

Skattereformen, også kendt som 'fusionen af det kommunale og statslige skatteområde', blev som tidligere nævnt implementeret i 2005. De neoliberale tanker sætter således deres spor på linje med NPM-tankegangen. Allerede inden skattereformen i 2005 var Fogh som skatteminister i Schlüterregeringen blevet kendt for at effektivisere skattevæsenet. Foghs tankegang om "Minimalstaten" 
har, på trods af den senere nedtoning af dette, uden tvivl spillet ind i beslutningen om VKregeringens besparelser og centralisering af skattevæsenet, som fusionen i 2005 medførte. Anders Fogh Rasmussen har siden kollapset i SKAT selv afvist sammenhæng mellem SKAT's problemer og de neo-liberalistiske tanker, der ligger til grund for strukturreformen.

De borgerlige partier stod dog ikke alene med ønsket om at videreføre centraliseringen og effektiviseringerne i SKAT. Fx udtaler tidligere Skatteminister, Thor Møger-Petersen, (SF), til Politiken den 30. august 2012: "Samlet set er det vores vurdering, at ved at gøre tingene smartere, kan vi $i$ den samlede organisation spare godt 1.000 årsvark frem til 2016." Den efterfølgende skatteminister Holger K. Nielsen fortsætter den linje på et møde den 26. juni 2013 i samråd i Skatteudvalget: "Det er vores helt klare vurdering, at det at der bliver farre ansatte i SKAT, ikke går ud over kvaliteten af SKAT's arbejde."

Der eksisterer altså politiske visioner på tværs af partiprogrammer og politiske ståsteder, der er kendetegnet af centralisering og effektivisering. Således stopper besparelserne og effektiviseringerne ikke i SKAT på trods af, at nye regeringer kommer og går.

Besparelserne i SKAT er dog ikke det eneste område, der er politisk fokus på. Selve kerneopgaven for SKAT er også under politisk behandling. Således udtaler Kristian Jensen i sin tid som Skatteminister: "Jeg har hele tiden sagt, at SKAT skal både vare en servicevirksomhed og en kontrolvirksomhed" (Skeletterne i SKAT, DR, 2016). Denne ændring i forståelsen af SKAT's kerneopgave har haft stor påvirkning på medarbejder- og ledelsesniveauet, men er altså udover at have ophæng i NPM-tankegangen også initieret af et politisk ønske om, at SKAT både skal være en kontrolinstans og en servicevirksomhed.

De formulerede politiske visioner fra Foghs skattereform i 2005 bliver således en del af rammen for den meningsskabelse, der finder sted på det politiske niveau også i mange år efter, at Foghregeringen var gået af. Baseret på et fundament af neoliberale tanker, forstørres de ledetråde, der omhandler effektivitet og centralisering. Visionen giver retrospektivt og kontinuerligt mening for politikerne, fordi det neoliberale ideal danner fundament for Konkurrencestaten, som bliver det altoverskyggende paradigme op igennem oo'erne og 10’erne. 


\section{F. Sammenfatning - Gav det mening, SKAT?}

Gennem ovenstående analyse har vi forsøgt at anskueliggøre, hvilke meningsskabende elementer, der var afgørende for den meningsskabelse, der fandt sted i SKAT i tiden op til og omkring udbyttesvindlen. Dette har vi gjort på både medarbejder-, ledelses- og organisationsniveau for at vise, hvordan disse meningsskabende elementer i sidste ende blev afgørende for de til- og fravalg, der blev taget i SKAT. Overordnet set var meningsskabelsen på organisationsniveau påvirket af fire afgørende faktorer: Magtforholdet til Finansministeriet, konsulenthusene der gemte sig i kulissen, New Public Management-paradigmet samt politiske visioner

De fire faktorer er ikke rangordnet, men spiller hver især en afgørende rolle i den meningsskabelse, der skete i SKAT. Gennem diverse forbindelsestråde skabes et mønster af meningsskabelse, der går på tværs af de tre niveauer gennem meningsskabende sekvenser.

Således danner de fire faktorer baggrunden for et mønster, der trækker tråde helt tilbage til de neoliberale visioner fra Reagan og Thatcher, forbi Rønnows resultatkontrakt og til skattemedarbejderen Sven.

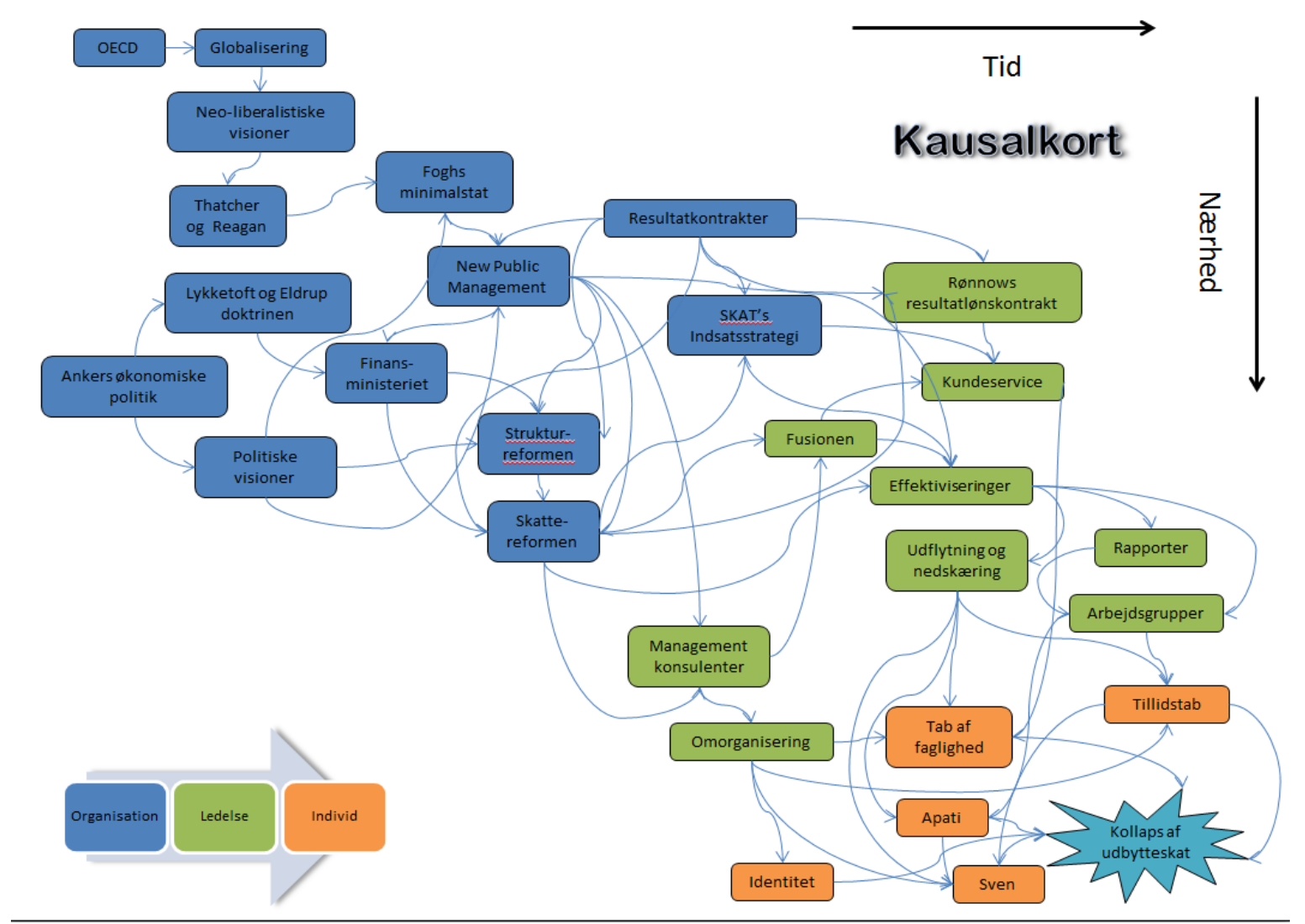


Der er, som det ses i kausalkortet, tale om et indviklet mønster af tråde mellem diverse meningsskabende begivenheder. Dette mønster af tråde blev determinerende for de til- og fravalg, der blev taget i SKAT og dermed afgørende for at kollapset kunne ske.

\section{Kollapset i udbytteskat}

Weick konkluderer om Mann Gulch, at brandmændene “mistede deres sociale anker, da de blev i tvivl om, i hvor høj grad de kunne have tillid til deres leder, og da de blev fremmede for hinanden" (Weick, 2001). På samme måde så vi i det ovenstående, at medarbejderne på udbytteområdet i SKAT mistede deres sociale anker, da de fandt det svært at kommunikere. Den dårlige relation, påvirket af mangel på tillid og at man simpelthen ikke kendte hinanden, påvirkede således meningsskabelseskollapset. I forbindelse med at medarbejderne ikke befandt sig i et miljø, der opmuntrede til samtale, blev det meningsskabende element sociale processer således afgørende for kollapset.

På ledelsesniveauet fik det, som vist i den ovenstående analyse, afgørende betydning for de handlinger, man foretog, at de ikke gav mening i forhold til situationen. I Mann Gulch gav lederens handling ikke mening for brandmændene: "[they] were unclear where and when they would take a stand to suppress the fire, what their actions were accomplishing, and whether they might even be making things worse by enacting a new fire (Weick, 2001). I SKAT gav ledernes handlinger heller ikke mening for medarbejderne.

Handlingen at nedsætte arbejdsgrupper gav ikke mening blandt de ansatte, eftersom de mange rapporter, der blev udarbejdet, øjensynligt blot medførte beslutninger om nye undersøgelser, arbejdsgrupper og rapporter. Ligeledes gav heller ikke politikernes handlinger mening for medarbejderne, da de blev ved med at iværksætte nye besparelser og effektiviseringer, på trods af at medarbejderne i årevis havde lidt under lignende tiltag. Således havde det meningsskabende element handling ('enactment') stor betydning for meningskollapset på udbytteområdet.

På det organisatoriske niveau bidrog forholdet mellem Finansministeriet og Skatteministeriet, herunder SKAT, til meningsskabelsen i en kontinuerlig proces og ved hjælp af ledetråde. Brandmændene i Mann Gulch stod over for "Cues that were difficult to interpret. They did not know whether they were retreating from the fire or flanking it, whether it was big or small... and whether they 
should flee or face" (Weick, 2001). I SKAT påvirkedes den organisatoriske meningsskabelse kontinuerligt over en lang årrække af politiske visioner, herunder NPM, og konsulenthusenes indflydelse samt forholdet til Finansministeriet. Fokusskiftet fra skattefaglighed og kontrol til service og effektivitet medvirkede dermed til den meningsskabelse, der fandt sted fra det organisatoriske niveau gennem ledelses- til medarbejderniveauet. Særligt blev de meningsskabende ledetråde, der omhandlede effektivitet og centralisering forstørret, hvorved kimen til, at udbyttesvindlen kunne ske, blev lagt.

På samme måde som brandmændene insisterede på, at der var tale om en 10 o'clock fire (en mindre ildebrand) (Weick, 2001, s. 465) insisterede også lederne i SKAT på, at der ikke var noget galt. Derfor tyede de til at nedsætte arbejdsgrupper, i stedet for at skabe handling ud fra de opråb, medarbejderne kom med. Brandmændene i Mann Gulch kunne ikke trække på “retrospective sensemaking because they did not know what was going on, their actions were unclear, and there was no explanation of why their foreman was adding a new fire” (Weick, 200 1, s. 465). Når meningsskabelse sker retrospektivt, og der i tiden op til og omkring udbyttesagen ikke var nogle erfaringer at trække på i forhold til svindel for milliarder, skabte lederne således ikke ny meningsskabelse i den henseende, men forblev i den kendte ramme for meningsskabelsen. For brandmændene i Mann Gulch var det ikke plausibelt: "that the fire they had expected to find had grown monstrous." (Weick, 2001). For lederne i SKAT var det således heller ikke plausibelt, at svindel i et så gigantisk omfang kunne ske.

Lederne i SKAT fokuserede på de mange brande, der skulle slukkes andre steder, hvilket således banede vejen for en altomfattende brand på udbytteområdet, og kollapset på udbytteområdet skete præcis som i Mann Gulch: "Little screw-ups that fitted together tighter and tighter until all became one and the same thing - the fateful blowup" (Weick, 1996).

På både ledelses- og medarbejderniveau var identiteten medvirkende til kollapset på grund af de skift, der skete i fokus væk fra faglighed og over imod service og generaliseret viden. Ledere og medarbejdere hos SKAT havde tidligere haft en identitet, der beroede på detaljeret og teknisk skatteindsigt, og som tog udgangspunkt i kontrol. I Mann Gulch blev det fatalt, at brandmændene: "found their identity threatened when they were told to drop their tools" (Weick, 2001, s. 465). Således blev også medarbejdere og lederes 'gamle' identitetsopfattelse truet.

Medarbejderen gik fra at være fagligt specialiseret til, at skulle fokusere på service, mens ledelse i 
højere grad handlede om management, jf. NPM-dagsordenen. På medarbejderniveau tog identitetsskiftet fra faglighed overhånd, som vist ved dette citat: “ $N a ̊$, men når jeg ikke må lave kontrol, så skal jeg nok 100\% lave service. Og ikke lave noget kontrol” (Skeletterne i SKAT, DR, 2016).

På baggrund af Weicks analyse af Mann Gulch så vi, hvilke fatale konsekvenser det kan få, når ledere fejlagtigt tror, at deres medarbejdere har tillid til dem. Således kan det siges, at medarbejdernes manglende tillid til ledelsesniveauet i SKAT var stærkt medvirkende til det ultimative kollaps.

Med ovenstående analyse af kollapset på udbytteområdet har vi således vist, at et mønster meningsskabende elementer i en kombination blev afgørende for den meningsskabelse, der førte til, at kollapset på udbytteskatteområdet fandt sted.

\section{Resiliens og robusthed}

Udbytteskatteområdet kollapsede - men hvorfor kunne SKAT ikke overleve krisen? Som vist har opbygningen af organisatorisk resiliens, påvirkning på evnen til at gennemleve, eller sågar overleve, kriser. Resiliens kan medvirke til at modstå et kollaps.

Med udgangspunkt i det mønster af meningsskabelse, som blev afgørende for udbytteskandalen, vil vi nu, som det fremgår af vores problemformulering dykke ned i, hvilken betydning denne meningsskabelse havde for SKAT's resiliens.

Ifølge Weick er der fire karakteristika, der er afgørende for opbygningen af organisationers resiliens, nemlig: improvisation, visdom, respektfuld interaktion og kommunikation.

Improvisation er det første væsentlige led i opbygningen af resiliens. Det skyldes, at improvisatorer, ifølge Weick, forbliver kreative under pres og er i stand til at bringe orden i kaos. Den resiliente organisation vil have større overlevelsesevne, når meningsskabelse sker i miljøer, der udsættes for pludselige skift fra det forventede til det uventede, eller sågar til det ubegribelige (Weick, 1996, s. 145). Når noget uventet eller sågar uforståeligt sker, skal man ifølge Weick tage fat i dette uventede med henblik på: "bringing (it) to the surface, testing, and restructuring one’s intuitive understandings of phenomena on the spot, at a time where action can still make a difference" (Ibid.). I SKAT så vi, at såvel medarbejdere som ledere på udbytteområdet reagerede på det 
uventede ved at skabe handling retrospektivt, og med udgangspunkt i deres identitet. Således improviserede de ikke. I stedet udbetalte medarbejderne udbytterefusion med tanke på at servicere de ansøgende udenlandske borgere, og undervejs blot notere uregelmæssigheder ved at lave anmærkninger, mens ledelsen igen og igen nedsatte arbejdsgrupper og bestilte rapporter. Dermed blev der ikke givet opmærksomhed og plads til: testing and restructuring one's intuitive understandings of phenomena on the spot. Det betyder at det første af de fire resiliens-karakteristika ikke blev bragt i anvendelse i SKAT.

Visdom ('wisdom’) er ligeledes nødvendigt for opbygningen af resiliens. I organisationer vokser visdom og uvidenhed i henhold til Weick sammen, eftersom den visdom, der opbygges på et givent område, skaber uvidenhed indenfor andre områder.

I SKAT har man gennem mange år opbygget en organisation, der har været højt specialiseret i at udføre kontroller på skatteområdet med udgangspunkt i en skattefaglig baggrund. Men over de seneste ti år er viden i højere grad blevet ændret til et generalistniveau. Derudover er der sket så mange strukturelle ændringer i organisationen, at den opbyggede visdom på det skattefaglige område er blevet udfordret.

Den visdom, som medarbejdere såvel som ledere i SKAT gennem årene havde opbygget, tog udgangspunkt i kontrol og skattefaglighed. Med den nye medarbejderskare og fokus på service frem for kontrol, som følge af de ovennævnte ændringer og ikke mindst indsatsstrategien, skete der dog ændringer i kontrolregimet i SKAT. Det betød ifølge en tidligere medarbejder, at man i modsætning til tidligere udførte risikobaseret kontrol, hvorved man gik fra at kontrollere alle områder i eksempelvis en virksomhed, til kun at kontrollere de områder, hvor der var størst risiko for, at snyd eller uregelmæssigheder fandt sted. Organisationen havde således historisk opbygget et stort repertoire af viden og kompetencer til at kontrollere inden for højt specialiserede områder, hvilket tilsyneladende betød, at der var resiliens nok til at forhindre, at et større kollaps kunne finde sted. Således synes de tidligere totale revisionskontroller at have holdt resiliensen ved lige.

Til gengæld tyder det på, at skiftet, der skete med indførelsen af servicedagsordenen, indsatsstrategien, betød, at den visdom, der dermed blev opbygget, påvirkede SKATs resiliens uhensigtsmæssigt. 
Respektfuld interaktion er det tredje ben i opbygningen af resiliens, og den er kendetegnet ved tre ting; tillid, ærlighed og selvrespekt. I SKAT var der mangel på tillid og gensidig respekt. Som vist tidligere, følte medarbejderne ikke, at der blev lyttet til dem, og de havde kun ringe tillid til deres ledere, som de til tider følte sig intimideret af.

Ifølge Weick er det problematisk for organisationer, når tillid, ærlighed og selvrespekt er underudviklet. Det skyldes, at individet i sådanne tilfælde bliver overladt til sig selv, og som oftest bliver grebet af frygt, der vil påvirke dets dømmekraft og handlekraft. Dermed kan miljøet i SKAT siges at have medvirket til, at respektfuld interaktion var en mangelvare, hvorved organisationens resiliens er blevet yderligere svækket. Ikke mindst fordi respektfuld interaktion er forudsætningen for kommunikation. For ifølge Weick kan kommunikation kun foregå, hvis der er tid og tillid.

Kommunikation er således det fjerde element, en organisation skal fokusere på, i forbindelse med opbygning af resiliens. "Evidence is growing that nonstop talk is crucial in complex systems that are susceptible to disasters (Weick, 1996). Som vist,var der ikke et miljø i SKAT, hvor respektfuld interaktion var fremherskende. Der var en høj grad af mangel på gensidig respekt og tillid. Dermed var der ikke grobund for kommunikation. Under sådanne omstændigheder er det både svært at have fuld tillid til sine kolleger, for ikke at tale om at følge anvisningerne fra ledere, man ikke kender, og hvis instrukser ingen mening giver.

Den altafgørende kommunikation var tydeligvis fraværende i SKAT. Som vist tidligere i analysen havde man på medarbejderniveau en helt anden opfattelse af ledelsens kommunikation, end ledelsen selv havde. Dette kommer også til udtryk i følgende udtalelse fra Jesper Rønnow om svindlen med udbytterefusion: "Men det er ikke sådan, at hvis man som skattemedarbejder er ved at revidere et eller andet, og man står lige ved siden af, og der også er 1/2 mio. et eller andet sted, der er snydt for, hvis det er det, der er tale om, så har vi faktisk..., så har den pågaldende medarbejder faktisk en pligt til også at tage den sag”. Journalist: "Men noget kunne tyde på, at det budskab så ikke er kommunikeret tilstrakkeligt godt ud til samtlige medarbejdere i organisationen?” Jesper Rønnow: "Der er stadig masser af rum og plads til debat og diskussion om, lige precis det der, fordi det er inde og rore ved kernen af noget af den omstilling, som vi prøver at arbejde med" (Skeletterne i SKAT, DR, 2016). 
Således var der i SKAT ikke plads til den kommunikation, der ifølge Weick er altafgørende for opbygningen af resiliens i en organisation. En organisatorisk ramme tilbyder fx roller og ansvar, der er veldefinerede, hvorved forventningerne til dem bliver tydelige (Weick, 1993, s. 643). På trods af, at dette ifølge Weick er vanskeligt, eftersom “many role systems do not change fast enough, to keep up with a rapidly changing environment", er det væsentligt kontinuerligt at genskabe mening med disse roller og ansvar. Weick anfører, at "The only form that can keep up, is one based on face-toface interaction. And it is here, rather than in routines, that we are best able to see the core of organizing." (Weick, 1993). Han understreger videre pointen om at "nonstop talk is a crucial of coordination in complex systems that are susceptible to disasters" (Weick, 1993).

I SKAT og udbyttesagen var der ikke plads til meget face-to-face interaction, der kunne bidrage til at sikre systemets evne "to keep up with a rapidly changing environment".

Den meningsskabelse, der fandt sted, påvirkede, at SKAT's resiliens blev svækket på en sådan måde, at kollapset skete. Resiliensen i SKAT var svækket, dels gennem fraværet af respektfuld interaktion og kommunikation samt den manglende evne til at improvisere, dels var den svækket af den visdom, der gennem de seneste ti år var blevet opbygget.

For at kunne drage den optimale ledelsesmæssige og organisatoriske læring af kollapset på udbytteskatteområdet, vil det således være relevant at kunne pege på, hvorledes et mere resilient SKAT kan udvikles.

\section{G. Konklusion}

Artiklen har udforsket, hvordan Weicks syn på organisationer som løst koblede systemer bidrager til en ny forståelse af kollapset i SKAT ved at se på hvilke meningsskabende elementer, der var afgørende for den meningsskabelse, der fandt sted i SKAT i tiden op til og omkring udbyttesvindlen. Derudover undersøgte artiklen, hvordan denne meningsskabelse påvirkede SKAT's resiliens.

Ved at anse SKAT som et løst koblet system bevægede vi os væk fra grundantagelsen om, at det alene var udøvelsen af ledernes magt og korrekte forretningsgange, der blev afgørende for, hvad 
der skete i SKAT. SKAT var således i Weicks optik at betragte som et sårbart system af specialiserede individer.

Denne forståelse af SKAT skabte fundamentet for vores analyse af, hvilke meningsskabende elementer der blev afgørende for, at udbyttesvindlen kunne finde sted. Ved at finde og gennemgå meningsskabende sekvenser på henholdsvis medarbejder-, ledelses-, og organisationsniveau kom vi frem til, at udbyttesvindlen i SKAT kunne ske, fordi et mønster af tråde af meningsskabende sekvenser muliggjorde dette. Dette illustrerede vi i vores kausalkort. Udbyttesvindlen kan således begrundes i et komplekst mønster af meningsskabelse, der trækker tråde helt tilbage til den neoliberale tanke, strukturreformen og Lykketofts og Eldrups reformering af Finansministeriet, som vist i kausalkortet.

På baggrund af dette påviste vi, at et mønster af alle Weicks syv meningsskabende elementer i en kombination blev afgørende for den meningsskabelse, der førte til, at kollapset på udbytteskatteområdet fandt sted.

SKAT's resiliens blev svækket af den meningsskabelse, der skete i SKAT. Dels gennem fraværet af respektfuld interaktion, kommunikation og den manglende evne til at improvisere, dels var den svækket af den visdom, der var blevet opbygget gennem de seneste ti år.

Weicks syn på organisationer som løst koblede systemer bidrager således til en ny forståelse af kollapset i SKAT ved at tvinge os væk fra idéen om ansvar og hierarki. Gennem Weick får vi øjnene op for de sociale processer og meningsskabende elementer, der spillede en afgørende rolle for de til- og fravalg, der blev taget i SKAT i tiden op til og omkring, at udbyttesvindlen fandt sted. Det er således tydeligt, at udbyttesvindlen i SKAT var funderet i et mønster af meningsskabende sekvenser, og at denne meningsskabelse blev afgørende for organisationens resiliens. Det giver således jf. Weick slet ikke mening at tale om enkeltpersoners ansvar.

Det er således vores konklusion på baggrund af denne artikel, at ønsker man at forstå og få indsigt i, hvorfor og hvordan organisationer kollapser, er organisationsopfattelsen altafgørende. Først ved at fralægge sig den klassiske organisationsopfattelse og dens fokus på ansvar, hierarki og beslutningstagen, kan man få øjnene op for de bagvedliggende strukturer og mønstre og dermed 
den meningsskabelse der netop er afgørende for hvilke beslutninger, der træffes og ikke træffes. Med Weicks egne ord: "Sensemaking sets the frame within which decisions are made"- Karl E. Weick.

\section{H. Kan det ske igen?}

Ved at dykke ned i kollapset i SKAT har vi gennem Weick fået øje for, hvor stor betydning meningsskabelse spiller for en organisation. Og som beskrevet i indledningen hører vi jungletrommerne lyde andre steder i det offentlige. Det er dermed nærliggende at stille spørgsmålet: Hvis det kan ske i SKAT, kan det så (også) ske i andre offentlige organisationer?

I vores analyse af meningsskabelsen i SKAT var det tydeligt, at kollapset i SKAT skete på baggrund af en lang række af meningsskabende sekvenser på både medarbejder-, ledelses- og organisationsniveau. Interessant er det således at bemærke, at de fire faktorer, vi i vores analyse fandt frem til, var afgørende for den meningsskabelse, der fandt sted på organisatorisk niveau i SKAT, alle var faktorer, der også vil kunne påvirke meningsskabelsen i andre offentlige organisationer. Der var tale om følgende faktorer:

\section{Magtforholdet til Finansministeriet \\ Konsulenthusene, der gemte sig i kulissen \\ New Public Management-paradigmet \\ Politiske visioner}

Ingen af disse faktorer knytter sig alene til SKAT og eller Skatteministeriet. De spiller tværtimod alle en stor rolle generelt i den offentlige forvaltning.

Overordnet set er det muligt at genkende mange mønstre fra Strukturreformen og effektiviseringerne i SKAT i en lang række andre offentlige organisationer. Det behøver ikke nødvendigvis at være bekymrende i sig selv, at offentlige organisationer gennemgår strukturelle ændringer og effektiviseringer. Det er efterhånden en indforstået præmis i debatten om den offentlige sektor. Men der er alligevel nogle offentlige organisationer, hvor vi ser medarbejdere og ledere, der står i samme situation som medarbejderne i SKAT - de kan heller ikke skabe mening i den forandringsproces, de står i. 
Vi hører jævnligt bekymret sundhedsfagligt personale på hospitaler mv., hvor bl.a. besparelser og indførsel af nye teknologier er hverdagskost. Debatten om implementering af 'Sundhedsplatformen’ er et eksempel på en teknologi, der indføres, og hvor især lægerne har svært ved at skabe mening i denne teknologi, da den reformulerer deres faglige identitet. Lægernes identitetskrise ligner brandmændenes i The Mann Gulch-katastrofen: "Hvis jeg sidder bag en computerskærm, er jeg så læge?” Og “hvis jeg ikke er læge, hvad er jeg så?”. Måske ser vi tilløbet til en ny skandale, hvor det udskældte godt nok er et IT-system, men egentlig handler om læger, der ikke kan skabe mening?

Vi hører ligeledes i medierne om plejepersonale, pædagoger og politi, der råber vagt i gevær over NPM-dagsordenen, effektiviseringer samt mangel på tid og ressourcer.

I kulissen lurer Finansministeriet samt konsulenthusene med beregninger, der viser store effektiviseringspotentialer i offentlige organisationer. Og noget tyder på, at uanset hvilket parti, der sidder på magten, så er den grundlæggende politiske vision bundet op omkring samme vision om en enkel og effektiv offentlig sektor, der, som vi har set, trækker tråde tilbage til den neoliberale ideologi. 


\section{Referenceliste}

Analyse af Skatteministeriet, rapport udarbejdet af Mckinsey \& company, december 2012.

Andersen, Camilla Heding; Hansen, Lotte Maglehøj og Lund, Morten Willas (2017) Giver det mening, SKAT? Hovedopgave Master in Public Administration, CBS.

Aftale mellem Regeringen, DF, S, SF og RV: Aftale om iværksættelse af en advokatundersøgelse af SKATs udbetaling af refusion af udbytteskat, Folketinget, 16. december 2016.

Berg-Sørensen, Anders, et al. (2013) Organiseringen Af Den Offentlige Sektor: Grundbog i Offentlig Forvaltning. Hans Reitzel.

Beretning til Statsrevisorerne om SKATs forvaltning af og Skatteministeriets tilsyn med refusion af udbytteskat, Rigsrevisionen, februar 2016.

Christensen, Jørgen Grønnegård og Mortensen, Peter Bjerre (2018). Overmod og afmagt - Historien om det nye SKAT. DJØF Forlag.

Faktuel redegørelse om administrationen af udbytterefusion i perioden 2010-2015, SKAT af borger- og retssikkerhedschefen i SKAT, februar 2016.

Hammer, Sverri, og James Høpner (2015). Meningsskabelse, Organisering Og Ledelse: En Introduktion Til Weicks Univers. Samfundslitteratur,

Kommissorium for advokatundersøgelse af forholdene vedrørende SKATs udbetaling af refusion af udbytteskat, Skatteministeriet, 16. december 2016.

Kundeservicestrategi 2014 - Kunden i centrum, skatten i balance

Ministerredegørelse til statsrevisorernes beretning nr. 11/2015 om SKATs forvaltning af og Skatteministeriet tilsyn med refusion af udbetaling af udbytteskat, Skatteministeriet, 4. maj 2016.

Notat til Statsrevisorerne om tilrettelæggelsen af en større undersøgelse af SKATs kontrolsvigt i forbindelse med refusion af udbytteskat, Rigsrevisionen, oktober 2015.

Pedersen, Ove Kaj. (2011) Konkurrencestaten. Hans Reitzels Forlag.

Politiken 25. februar 2016 - Skat udbetalte milliarder trods advarsel 
Politiken 6. marts 2016 - SKAT fyrede sin egen vagthund

Politiken 6. august 2016 - SKAT opdagede ikke, at de blev svindlet for deres egne penge

Politiken 17. december 2016 - Ansvar for skattesvindel peger opad

Politiken 17. december 2016 - Manden der ikke vil være skyldig

Politiken 26. december 2016 - Hemmelig Rapport: Alle vidste det sejlede i SKAT

Politiken 28. januar 2017 - SKAT godtog vrøvleforklaring på svindel for 12,3 milliarder

Politiken 12. februar 2017 - Skatteministeriets konsulenter undersøgte udbytteskat, mens svindlere lænsede statskassen

Politiken 6. august 2017 - Skat opdagede ikke at de blev svindlet for deres egne penge

Potentialet ved en fusioneret skatteadministration, rapport udarbejdet af Boston Consulting Group, maj 2005.

Resultatlønskontrakt Jesper Rønnow Simonsen, 2015.

Rigsrevisionen notat om beretning om SKATs forvaltning af Skatteministeriets tilsyn med refusion af udbytteskat, Rigsrevisionen, 3. juni 2016.

SKATs administration af udbytteskat og refusion, Skatteministeriets Interne Revision (SIR), 24. september 2015Skeletterne i SKAT; DR dokumentar om SKAT (2016)

Snook, Scott A. (2002) Friendly Fire: the Accidental Shootdown of U.S. Black Hawks over Northern Iraq. Princeton University Press.

TRACE Implementation Package for the Adoption of the Authorized Intermediary System - A Standardized System for Effective Withholding Tax Relief Procedures for Cross-Border Portfolio Income, 23. januar 2013.

Turnusanalyse af betalings- og regnskabsområdet, rapport udarbejdet af Deloitte, juni 2015.

Vikkelsø, Signe, and Peter Kjær. (2014) Klassisk Og Moderne Organisationsteori. Hans Reitzel. 
Andersen, Hansen, Lund og Madsen / Gav det mening, skat?

Weick, Karl E. (1996). Prepare Your Organization to Fight Fires. Harvard Business Review. MayJune

Weick, Karl E. (1993). "The Collapse of Sensemaking in Organizations: The Mann Gulch Disaster.” Administrative Science Quarterly, vol. 38, no. 4, p. 628-652, Sage Publications. https://doi.org/10.2307/2393339

Weick, Karl E. (2000) Sensemaking in Organizations. Sage Publications.

Weick, Karl E. (2001) Making Sense of the Organization. Blackwell.

Weick, Karl E., and Scott A. Snook. (2001) "Friendly Fire: The Accidental Shootdown of U.S. Black Hawks over Northern Iraq. Administrative Science Quarterly, vol. 46, no. 1, p. 147-151.

https://doi.org/10.2307/2667128 